\title{
APLIKASI SEWA MOBIL BERBASIS WEB PADA PT INDOMOBIL CAR RENTAL
}

\author{
Tri Pujadi \\ Jurusan Sistem Informasi, Fakultas Ilmu Komputer ,BINUS University \\ Jl. KH Syahdan No. 9 Palmerah Jakarta Barat 11480 \\ Telp. (021)5345830 ext.2234, Faks. (021)5300244 \\ tripujadi@binus.edu
}

\begin{abstract}
Indomobil Car Rental (IndoRent) is a rental firm providing service to customer by provides vehicle and qualified drivers. Firm has extensive network by utilizes all network from Indomobil Group. Besides it also have care service network that exists at several big cities in Indonesia. Common service problems for customer is limitation of the number of drivers to service customer, particularly at the busy days where it is difficult for customers to do reservation and get information to rent a car. Company website does not provide rent price and car amount information. This application design is developed from a financial application system therefore making it easy for users to conduct activity or transactions and service that progressively increases. Method for modelling by use of Rational Rose, meanwhile design web application utilizes Macromedia Dreamweaver, and Macromedia Flash MX and Swishmax for its animation.This application utilizes PHP and MySQL. The website of Indomobil Rental Car is expected to be more dynamic and can pull more visitors its, so increases firm performance.
\end{abstract}

Keywords: administration, web-based application system

\begin{abstract}
ABSTRAK
Indomobil Car Rental (IndoRent) perusahaan rental kendaraan berusaha memberikan layanan terbaik kepada pelanggan dengan menyediakan kendaraan serta pengemudi yang berkualitas. Perusahaan memiliki jaringan yang luas dengan memanfaatkan seluruh jaringan dari Indomobil Group. Selain itu juga memiliki jaringan layanan perawatan yang terdapat di beberapa kota besar di seluruh Indonesia. Masalah umum yang muncul dalam layanan untuk customer adalah keterbatasan pengemudi untuk melayani pelanggan, terutama pada waktu hari raya sehingga pelanggan sulit melakukan pemesanan dan memperoleh informasi. Sedangkan website yang ada belum menyediakan harga sewa dan jumlah mobil sehingga menyulitkan dalam melakukan pemesanan. Tujuan desain ini adalah pengembangan dan perbaikan sebuah sistem aplikasi finansial sehingga memudahkan user melakukan aktivitas atau transaksi dan pelayanan yang semakin meningkat. Model aplikasi dengan menggunakan tool Rational Rose, sedangkan desain aplikasi berbasis web menggunakan Macromedia dreamweaver, serta Macromedia Flash MX dan Swishmax untuk animasinya.; sedangkan pemrograman web menggunakan PHP dan MySQL. Akhirnya pengembangan website Indomobil Rental Car diharapkan akan lebih dinamis dan lebih menarik para pengunjungnya, sehingga meningkatkan kinerja perusahaan.
\end{abstract}

Kata kunci: penyewaan mobil, aplikasi web, layanan customer 


\section{PENDAHULUAN}

Indomobil Sukses International Tbk adalah satu kelompok usaha otomotif terkemuka di Indonesia. Perusahaan ini adalah agen tunggal pemegang merk (ATPM) dan distributor sembilan merek kendaraan terkenal yaitu Audi, Hino, Mazda, Nissan, Renault, Suzuki, Ssangyong, Volkswagen dan Volvo. Dalam bisnisnya mereka menjalin kerjasama dengan mitra lokal dan asing yang mempunyai reputasi internasional dan berpengalaman dibidangnya.

Indomobil Group sudah lebih dari 20 tahun bergerak di bidang otomotif dengan berbagai faktor pendukungnya seperti jaringan service di seluruh Indonesia dan dukungan dari berbagai macam bisnis usaha yang saling terkait. Saat ini perusahaan mempunyai lebih dari 40 unit bisnis atau anak perusahaan yang terutama bergerak pada jasa transportasi darat.

Melihat perkembangan bisnis rental jasa kendaraan yang berkembang didukung produk Indomobil yang lengkap, dan perlunya meningkatkan image produk Indomobil maka dibangun satu unit bisnis baru Indomobil Car Rental dengan nama PT. Wahana Indo Trada Mobilindo. Indomobil Car Rental (IndoRent) merupakan perusahaan yang bergerak dibidang rental kendaraan produk Indomobil yang memberikan fasilitas terbaik kepada customer serta menyediakan pengemudi yang berkualitas.

IndoRent memiliki Visi dan Misi yang menjadi landasan dalam bisnis penyediaan jasa transportasi. Visi IndoRent adalah "To be the best car rental service company in providing INDOMOBIL products." Sedangkan misinya yaitu "Selling and marketing will be the soul of our actions."

Beberapa keunggulan layanan IndoRent diantaranya Kemudahan perawatan dan perbaikan, Kemudahan mengatur cash flow, Ketersediaan kendaraan pengganti, Kemudahan mengurus asuransi , Kebebasan menentukan periode kontrak, Kebebasan memilih jenis kendaraan.

Indomobil Car Rental, dalam menjalankan bisnisnya memiliki added value yang diberikan pada para pelanggannya yaitu ; dibawah nama besar Indomobil Group (langsung dari ATPM), Jaringan service yang didukung oleh lebih dari 200 bengkel yang tersebar dari 28 propinsi di Indonesia, dapat memberikan paket service secara keseluruhan, berpengalaman dalam bisnis automotif , menyediakan berbagai macam type kendaraan yang sangat luas dari kendaraan produk-produk Indomobil Group dan klasifikasi driver, secara professional dalam menjalankan bisnis sewa kendaraan yang terfokus pada kepuasan pelanggan, memberikan jasa layanan Emas 24 dan Towing Car. Untuk itu setiap mobil yang disewakan ke para pelanggan, akan ditangani langsung oleh para karyawan yang professional dari berbagai department.

\section{Line Business}

Bisnis IndoRent dibedakan menjadi dua bagian, dilihat dari jangka waktu penyewaan, yaitu Longt term dan Short Term. Long term yang dipergunakan di Indomobil Car Rental adalah bentuk dari konsep Operational Lease. Leasing ini merupakan jangka waktu dari sewa minimal 1 bulan hingga batas waktu yang ditentukan dari kesepakatan bersama antara customer dan Indomobil Car Rental. Rental long tem ini merupakan solusi untuk mengatasi masalah yang dihadapi oleh customer, diantarany : investasi awal untuk pembelian mobil yang sangat tinggi, Biaya perawatan unit yang tidak terprediksi, penanganan sendiri untuk maintenance/service, penanganan claim asuransi, penanganan kecelakaan, tidak terdapat kendaraan pengganti, driver

Short term merupakan jangka waktu penyewaan yang ditawarkan untuk memenuhi 
kebutuhan pelanggan / customer dengan masa sewa di bawah 1 bulan. Rental Short Term ini merupakan solusi untuk mengatasi masalah yang dihadapi oleh customer, yaitu lelah dalam mengendarai kendaraan sendiri / pribadi terutama dalam perjalanan ke luar kota, kekhawatiran dengan kondisi keamanan dimana sering terjadi pencurian kendaraan bermotor, kondisi kendaraan umum yang tidak layak, menunggu perbaikan kendaraan pribadi untuk kerusakan teknis maupun body repair, kebutuhan kendaraan umum tamu / expatriate

Selain menyewakan unit kendaraan yang menjadi core bisnisnya, IndoRent juga menyediakan pengemudi yang berkualitas untuk melayani customernya. Driver merupakan salah satu bagian layanan yang ditawarkan oleh perusahaan agar memberikan kepuasan kepada customer melalui driver yang professional dan berkualitas. Indomobil Car Rental membedakan driver dengan klasifikasi A dan $\mathrm{B}$, dimana klasifikasi ini dilihat dari kemampuan driver itu sendiri tentang pengenalan jalan, keterampilan mengemudi, dan bahasa asing yang dikuasai terutama bahasa Inggris.

Indomobil Car Rental memiliki jaringan yang sangat luas dengan memanfaatkan seluruh jaringan dari Indomobil Group. Untuk operasional rentalnya dipusatkan di Jalan Raya Pasar Minggu km.18,7 untuk area Jakarta dan Jalan Raya Juanda km.5 untuk area Surabaya.

Selain itu juga memiliki jaringan layanan perawatan yang terdapat di beberapa kota besar di seluruh Indonesia dengan jumlah bengkel lebih dari 200 bengkel yang tersebar di 78 kota di 28 propinsi . Tidak hanya pada cabang-cabang dari Indomobil Group yang tersebar diseluruh Indonesia, namun juga didukung oleh bengkel-bengkel dari dealer resmi yang ditunjuk oleh Indomobil.

\section{Identifikasi Masalah}

Berdasarkan analisis terhadap sistem yang berjalan diidentifikasikan beberapa temuan, antara lain keterbatasan pengemudi untuk melayani pelanggan, terutama pada waktu hari raya seperti Lebaran, Natal dan tahun baru. Saat itu umumnya pelanggan sulit melakukan reservasi dan memperoleh informasi yang diinginkan seperti tersedia atau tidaknya sebuah kendaraan yang diinginkan pelanggan dan juga ,apakah masih tersedia pengemudi yang siap untuk melakukan perjalanan yang dituju oleh pelanggan. Selain itu website tidak menyediakan harga sewa dan jumlah mobil yang masih tersedia untuk disewakan. Tidak selalu terupdatenya informasi di Website terutama pada saat banyaknya permintaan akan sewa mobil seperti hari libur panjang dimana pelanggan menginginkan pergi keluar kota dan sangat membutuhkan sewa mobil dan pengemudi.

\section{Rencana Pengembangan aplikasi}

Dalam pengembangan dan perbaikan sebuah sistem aplikasi finansial dari sebuah perusahaan dimaksudkan untuk memudahkan user melakukan aktivitas melalui beberapa aplikasi yang akan dibuat sebagai tools yang nantinya berguna untuk user dan perusahaan.

Penggunaan web sebagai media promosi dan untuk penjualan secara online memiliki beberapa Tujuan, diantaranya :

- Membuat sistem penyewaan mobil ini lebih efektif dengan meningkatkan hubungan dengan pelanggan

- Membuat tampilan website lebih dan variatif

- Website memberikan informasi tentang mobil yang selalu terupdate

- Pasar lebih meluas dan mudah dijangkau oleh para pelanggan

- Menekan biaya promosi dibandingkan dengan promosi melalui media lainya.

- Mempercepat pelayanan ke user.

Penggunaan web sebagai media promosi dan untuk penjualan secara online memiliki beberapa Kegunaan , diantaranya :

- Penggunaan web sebagai media promosi dan untuk penjualan secara online 
- Memberikan informasi yang selalu terupdate(termasuk database yang akan kami buat mengenai penyediaan informasi harga sewa dan jumlah mobil yang masih tersedia untuk disewakan)

- Dengan tampilan menarik website akan menarik para pelanggan

- Promosi lebih murah dibandingkan dengan promosi melalui media lainya.

- Mempermudah pelayanan kepada pelanggan.

\section{METODE}

\section{Analisa dan Desain}

Pengembangan aplikasi didahului dengan model visual untuk menggambarkan model dari software yang akan dibangun. Untuk membuat model sistem tersebut digunakan tool Rational Rose yang memakai standar UML.

UML (Unified Modeling Language) merupakan bahasa standar pemodelan visual dalam rekayasa software, memberikan cara standar untuk mengembangkan model bagi software yang akan dibangun dan memberikan bahasa pemodelan yang bebas dari berbagai bahasa pemrograman dan proses rekayasa. Penggunaan UML dapat mengatasi kerumitan dalam segi arsitektural sistem software yang sedang dibangun . Didalam komponen UML terdapat diagram untuk menggambarkan proses bisnis dan data didalmnya.

\section{Tools yang digunakan}

Setelah model aplikasi dibuat dengan Rational Rose, selanjutnya rancangan desain website dibuat dengan menggunakan program Macromedia dreamweaver karena kesederhanaan penggunaannya, dan mendukung berbagai macam bahasa pemrograman dan juga bahasa HTML maupun PHP.

Sedangkan untuk mengolah grafik/gambar dalam website, digunakan program Adobe Photoshop dan Photoimpact. Hal ini karena kemudahan, fasilitas dan fleksibilitas dan dukungan berbagai style dan efek-efek yang sangat membantu dalam membuat grafik. Program-program ini sangat membantu dan pemotongan grafik pada halaman web , dimana gambar dalam sebuah website sebaiknya tidak berukuran besar, dan jika memang perlu ukuran gambar yang besar hendaknya dipotong menjadi beberapa bagian yang lebih kecil.

Untuk Pembuatan Animasi digunakan Macromedia Flash $\boldsymbol{M X}$ dan Swishmax . Tools ini mempermudah dalam membuat animasi dengan tampilan yang menarik serta penggabungan dengan grafis yang telah dibuat sebelumnya di Adobe Photoshop dan Photoimpact, serta file yang dihasilkan ber-extensi "swf" yang sudah banyak dipakai oleh website-website lainya.

- Adobe Photoshop adalah perangkat lunak buatan Adobe yang dikhususkan untuk pengeditan foto/gambar dan pembuatan efek. Perangkat lunak ini banyak digunakan oleh fotografer digital dan perusahaan iklan. Pada versi kedelapan disebut dengan nama Photoshop CS, versi sembilan disebut Photoshop CS2 dan demikian seterusnya.

- Macromedia Dreamweaver merupakan program penyunting halaman web keluaran Macromedia. Program ini banyak digunakan oleh pengembang web karena fitur-fiturnya yang menarik dan kemudahan penggunaannya. Macromedia meluncurkan versi terakhir Macromedia Dreamweaver yaitu versi 8. 
Rational Rose adalah software yang memiliki perangkat pemodelan secara visual untuk membangun suatu solusi rekayasa piranti lunak dan pemodelan bisnis. Rational Rose memakai UML sebagai bahasa pemodelannya ditambah beberapa fitur lain yang membuatnya menjadi software pemodelan visual yang terkemuka. Beberapa fitur diantaranya adalah Rational Rose memiliki Rational Unified Process (RUP) dan juga memiliki kemampuan membuat solusi client/server yang dapat diterapkan dan didistribusikan dalam lingkungan sebuah perusahaan.Inc.

\section{HASIL DAN PEMBAHASAN}

\section{Inisiasi dan Analisis Sistem}

Sistem ini berupa website yang dibuat untuk memenuhi kebutuhan akan informasi yang akan disediakan untuk memberikan informasi kepada pelanggan tentang informasi mobill dan package yang diberikan indomobil-car-rental.

Sistem ini juga memudahkan customer dalam berhubungan dengan indomobil. Dengan pembuatan sistem ini adminnistrator maupun sales dapat mengupload informasi-informasi baru.

\section{Use Case Diagram}

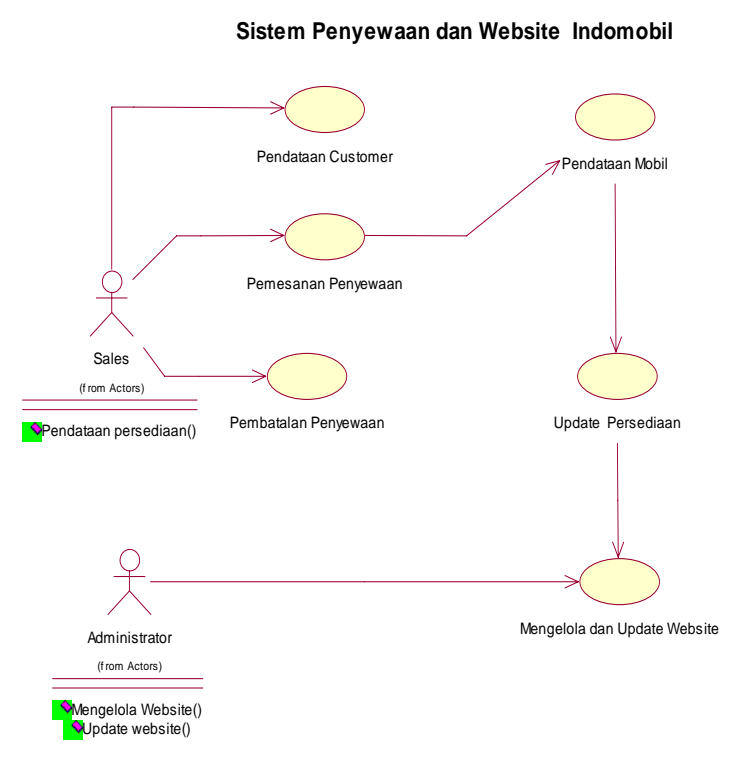

Gambar 1. Use Case Diagram Sistem Rental Mobil

Use Case Diagram pada gambar 1. menjelaskan tentang fungsi utama sistem dan Aktor yang berhubungan didalam system tersebut. Aktor didalam sistem terdiri dari bagian penjualan (sales), admin-sistem, dan customer. Edangkan fungsi sistem dinyatakan sebagai use case yang terdiri dari pendataan mobil dan driver, pendatan customer, pemesanan serta pembatalan sewa. Pendataan mobil dan customer adalah use case yang akan menjalankan fungsi menambah, memodifikasi dan menghapus data mobil maupun data customer. Sedangkan use case penyewaan pesanan dan pembatalan, mempunyai fungsi untuk memproses data pesanan mobil, melakukan update terhadap pesanan termasuk jika terjadi pembatalan. 


\section{Class Diagram}

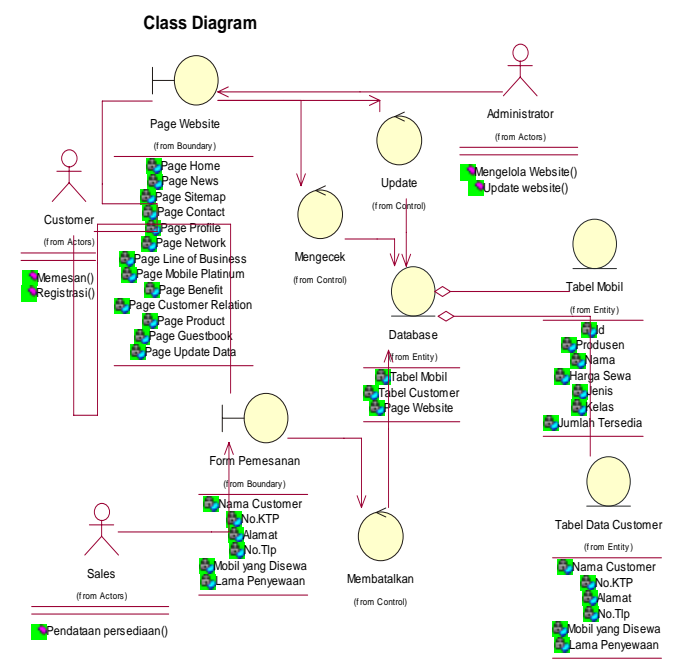

Gambar 2. Class Diagram Sistem Rental Mobil

Class diagram menampilkan entiti data, control dan boundary dalam sistem. Diagram yang terlihat pada gambar 2. tersebut juga memperlihatkan asosiasi antar classs data.

Pada class diagram tersebut hubungan interaksi diantara form data :

* Hubungannya antara Admin dengan page website adalah one-to-many dimana admin bisa membuka banyak page dan sebaliknya.

* Hubungan antara Admin dengan Form Login, Form Menu dan Page Reporting adalah one-to-many dimana admin bisa mengakses banyak Form Login, Form Menu dan Page Admin dan Form Login, Form Menu dan Page Admin hanya bisa diakses oleh 1 admin.

* Hubungan antara Customer dengan page - page yang ada di dalam website yaitu one-tomany dimana setiap customer bisa mengakses banyak halaman website dan halaman website hanya bisa diakses oleh 1 orang customer dalam 1 PC.

x Hubungan antara page produk dengan form pesanan dan form data customer ialah agregation dimana page ini terbentuk oleh form pesanan dan customer

\section{Sequence Diagram}

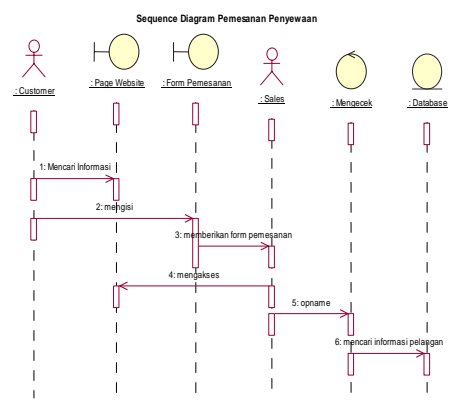

Gambar 3 Pemesanan produk (mobil) sewa

o Pertama sekali customer akan membuka page web sewa untuk membaca dan mencari informasi tentang produk mobil dan jadwal penyewaan,

o Kemudian customer akan memilih jadwal yang diinginkan. 
o Customer bisa memesan lewat telepon atau online didalam website.

o Jikalau memesan via telepon maka customer akan langsung menelepon Data customer akan dicatat dan diupdate ke database customer kemudian jadwal yang dipilh akan dicatat oleh staff dan kemudian diupdate ke database.

o Jikalau memesan online, maka setelah memilih jadwal di page sewa, customer bisa langsung meng-clik booking disamping jadwal yang dipilih.

o Maka akan muncul form isi data customer selanjutnya mengisi dan disubmit, lalu akan terjadi proses update terhadap database customer.

o Bersamaan dengan update akan terbuka form pesan yang harus diisi oleh customer.

o Setelah diisi dan disubmit maka akan terjadi proses update database pesanan.

o Kemudian customer akan menerima konfirmasi atas pesanan yang dilakukan.

\section{Statechart Diagram}

Aktivitas mengelola dan me-maintain website dimulai pada saat admin melihat dan memeriksa data dan informasi dalam website dan database. Selanjutnya admin akan memeriksa kebutuhan apakah perlu diadakan proses update data atau informasi. Apabila perlu proses update, maka akan dilakukian proses update baik itu website ataupun databasenya. Namun apabila tidak diperlukan maka admin melanjutkan aktivitas mengecek email kemudian melakukan aktiviats membalas email customer.

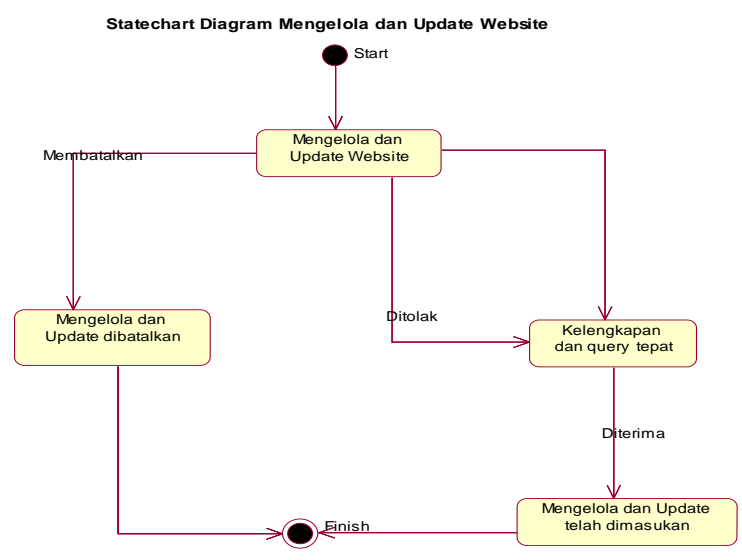

Gambar 4. Statechart Diagram Pengelolaan Website Penyewaan

Sedangkan urutan langkah dalam mengelola website oleh admin adalah sebagai berikut:

Pertama, Admin akan membuka page-page didalam website, kemudian melakukan proses check atas informasi-informasi yang ada. Kedua, apabila diperlukan input informasi ke page website maka akan dilakukan admin. Ketiga, setelah diinput informsi baru, maka akan terjadi proses update ke dalamm database MTT. Keempat, setelah itu admin akan membuka page email admin, kemudian membaca mail-mail yang masuk, dan kemudian membalas email.

\section{Component dan Deployment Diagram}

Diagram Component seperti terlihat pada gambar 5, memperlihatkan keterkaitan antara sistem dengan komponen sistem yang membangun sistem tersebut 


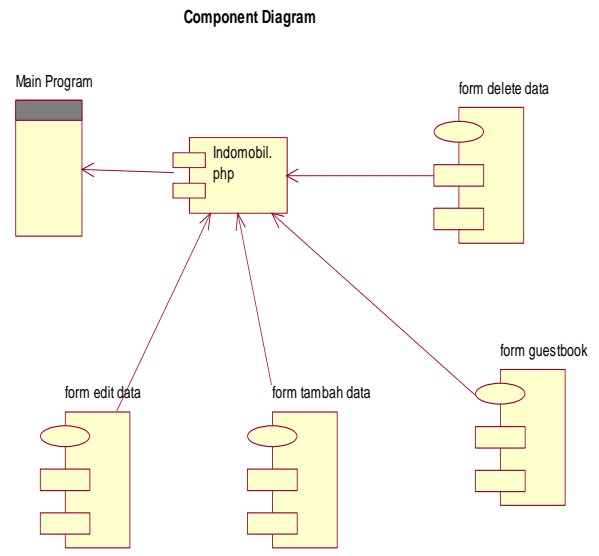

Gambar 5. Component Diagram Rental Mobil

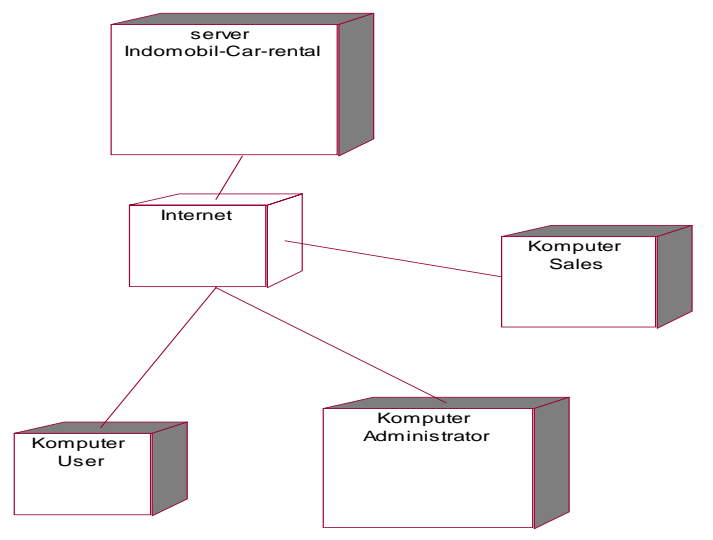

Gambar 6. Deployment Diagram Penyewaan Mobil

Deployment diagram adalah diagram yang memperlihatkan pemetaan software kepada hardware. Pemetaan tersebut adalah sebagai berikut :

\section{Dari sisi perusahaan :}

Sistem Aplikasi promosi dan generate report online akan diletakkan di application Server milik perusahaan, dimana semua data tentang services dan customer berikut dta pesanan akan disimpan di database server.Apllication server ini akan terhubung ke printer untuk mem-printout bukti pesanan customer, bukti pembayaran customer dan sales report.

\section{Dari sisi Customer:}

Customer bisa mengakses informasi ke website perusahaan dengan perantara Web server, baik itu lewat PC sendiri ataupun PC warnet.

Sistem ini berupa website yang dibuat untuk memenuhi kebutuhan akan informasi yang akan disediakan untuk memberikan informasi kepada pelanggan tentang informasi mobill dan package yang diberikan indomobil-car-rental. Sistem ini juga memudahkan customer dalam berhubungan dengan indomobil. Dengan pembuatan sistem ini adminnistrator maupun sales dapat mengupload informasiinformasi baru. 


\section{Use Case Diagram}

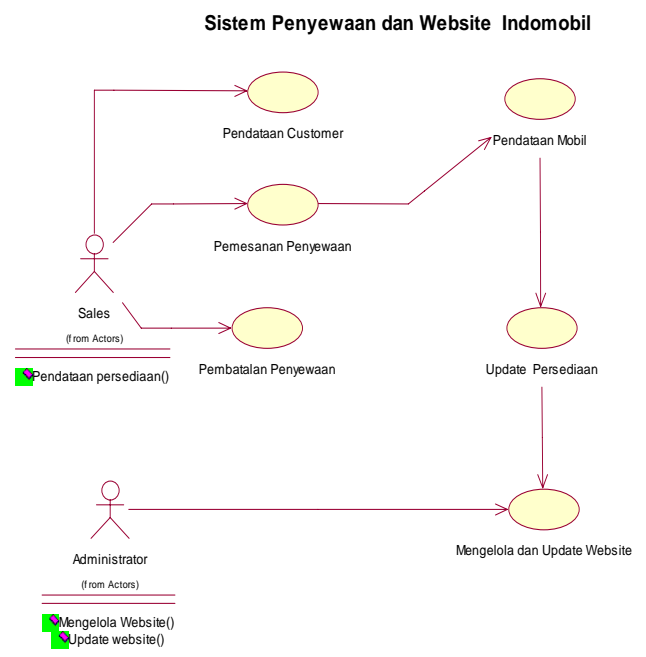

Gambar 1. Use Case Diagram Sistem Rental Mobil

Use Case Diagram pada gambar 1. menjelaskan tentang fungsi utama sistem dan Aktor yang berhubungan didalam system tersebut. Aktor didalam sistem terdiri dari bagian penjualan (sales), admin-sistem, dan customer. Edangkan fungsi sistem dinyatakan sebagai use case yang terdiri dari pendataan mobil dan driver, pendatan customer, pemesanan serta pembatalan sewa. Pendataan mobil dan customer adalah use case yang akan menjalankan fungsi menambah, memodifikasi dan menghapus data mobil maupun data customer. Sedangkan use case penyewaan pesanan dan pembatalan, mempunyai fungsi untuk memproses data pesanan mobil, melakukan update terhadap pesanan termasuk jika terjadi pembatalan.

\section{Class Diagram}

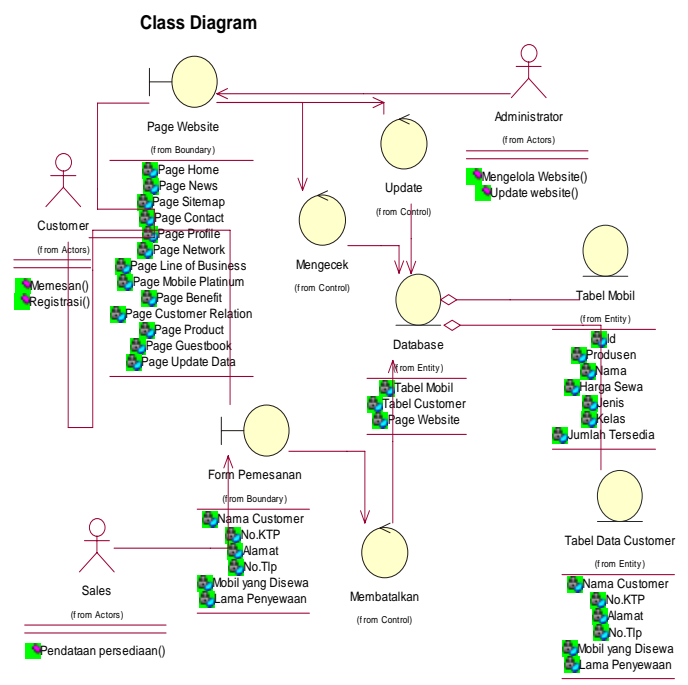

Gambar 2. Class Diagram Sistem Rental Mobil

Class diagram menampilkan entiti data, control dan boundary dalam sistem. Diagram yang 
terlihat pada gambar 2. tersebut juga memperlihatkan asosiasi antar classs data.

Pada class diagram tersebut hubungan interaksi diantara form data:

Pertama, hubungannya antara Admin dengan page website adalah one-to-many dimana admin bisa membuka banyak page dan sebaliknya. Kedua, hubungan antara Admin dengan Form Login, Form Menu dan Page Reporting adalah one-to-many dimana admin bisa mengakses banyak Form Login, Form Menu dan Page Admin dan Form Login, Form Menu dan Page Admin hanya bisa diakses oleh 1 admin. Ketiga, hubungan antara Customer dengan page - page yang ada di dalam website yaitu one-to-many dimana setiap customer bisa mengakses banyak halaman website dan halaman website hanya bisa diakses oleh 1 orang customer dalam 1 PC. Keempat, hubungan antara page produk dengan form pesanan dan form data customer ialah agregation dimana page ini terbentuk oleh form pesanan dan customer

\section{Sequence Diagram}

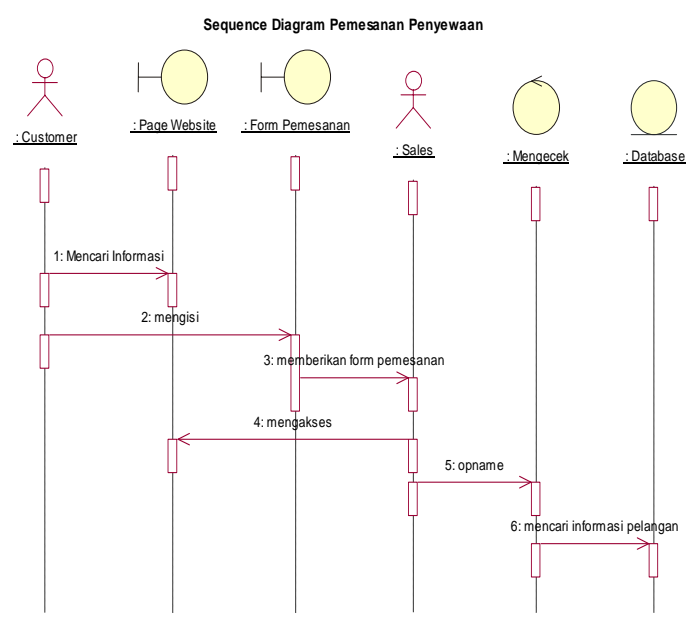

Gambar 3 Pemesanan produk (mobil) sewa

Pertama sekali customer akan membuka page web sewa untuk membaca dan mencari informasi tentang produk mobil dan jadwal penyewaan, kemudian customer akan memilih jadwal yang diinginkan. Customer bisa memesan lewat telepon atau online didalam website. Jikalau memesan via telepon maka customer akan langsung menelepon Data customer akan dicatat dan diupdate ke database customer kemudian jadwal yang dipilh akan dicatat oleh staff dan kemudian diupdate ke database. Jikalau memesan online, maka setelah memilih jadwal di page sewa, customer bisa langsung meng-clik booking disamping jadwal yang dipilih. Maka akan muncul form isi data customer selanjutnya mengisi dan disubmit, lalu akan terjadi proses update terhadap database customer. Bersamaan dengan update akan terbuka form pesan yang harus diisi oleh customer. Setelah diisi dan disubmit maka akan terjadi proses update database pesanan. Kemudian customer akan menerima konfirmasi atas pesanan yang dilakukan.

\section{Statechart Diagram}

Aktivitas mengelola dan me-maintain website dimulai pada saat admin melihat dan memeriksa data dan informasi dalam website dan database. Selanjutnya admin akan memeriksa kebutuhan apakah perlu diadakan proses update data atau informasi. Apabila perlu proses update, maka akan dilakukian proses update baik itu website ataupun databasenya. Namun apabila tidak 
diperlukan maka admin melanjutkan aktivitas mengecek email kemudian melakukan aktiviats membalas email customer.

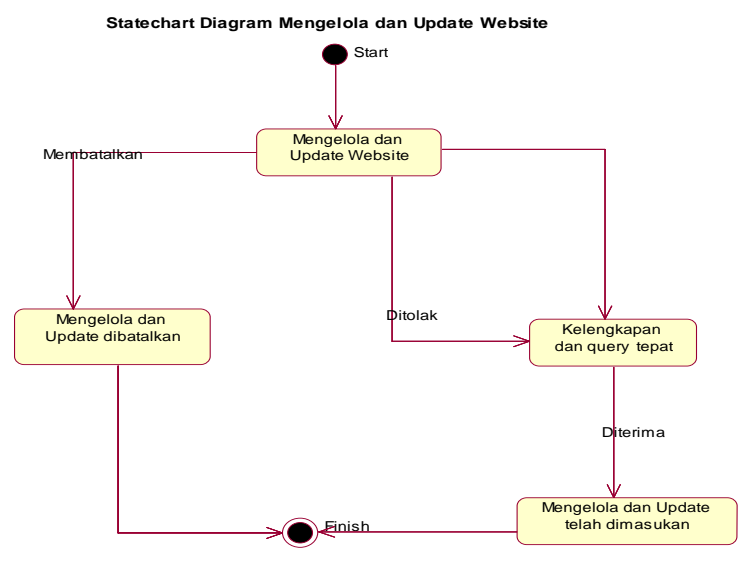

Gambar 4. Statechart Diagram Pengelolaan Website Penyewaan

Sedangkan urutan langkah dalam mengelola website oleh admin adalah sebagai berikut: Pertama, Admin akan membuka page-page didalam website, kemudian melakukan proses check atas informasi-informasi yang ada. Kedua, Apabila diperlukan input informasi ke page website maka akan dilakukan admin. Ketiga, Setelah diinput informsi baru, maka akan terjadi proses update ke dalamm database MTT. Keempat, Setelah itu admin akan membuka page email admin, kemudian membaca mail-mail yang masuk, dan kemudian membalas email.

\section{Component dan Deployment Diagram}

Diagram Component seperti terlihat pada gambar 5, memperlihatkan keterkaitan antara sistem dengan komponen sistem yang membangun sistem tersebut

Component Diagram

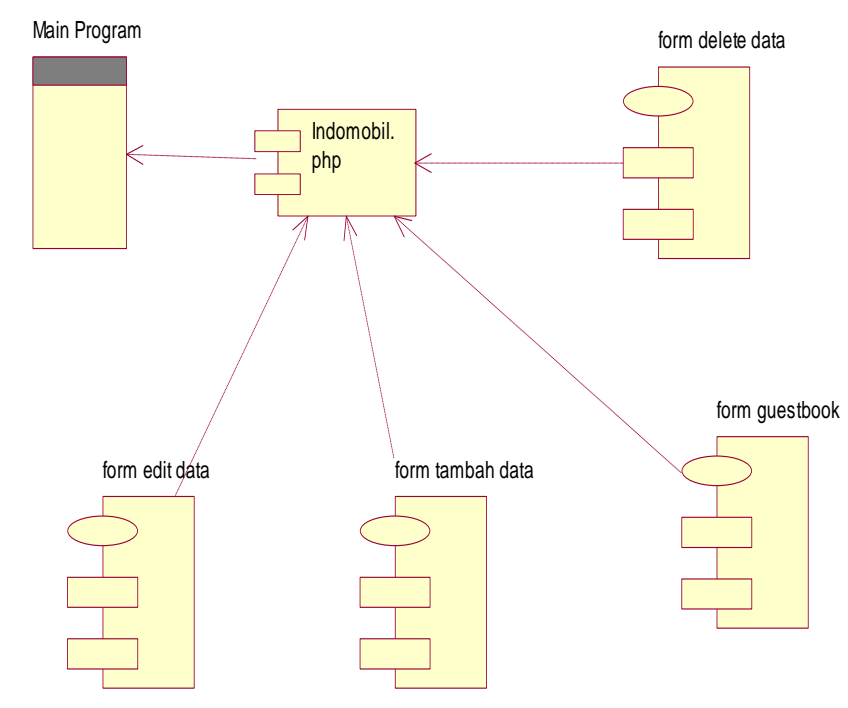

Gambar 5. Component Diagram Rental Mobil 


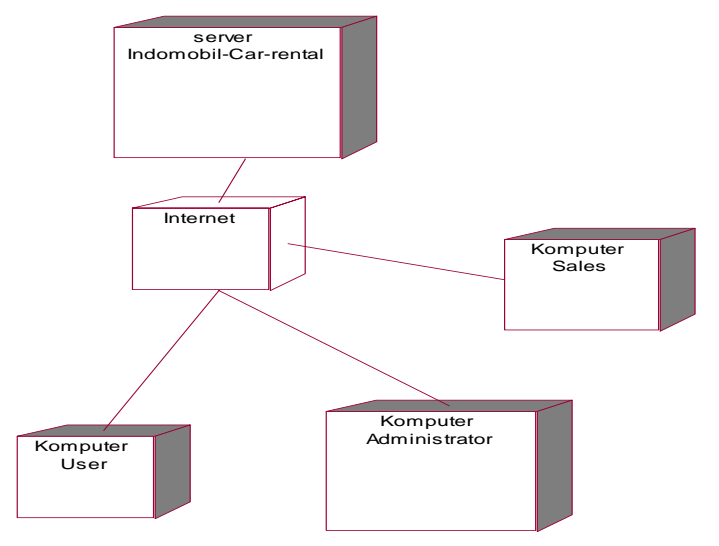

Gambar 6. Deployment Diagram Penyewaan Mobil

Deployment diagram adalah diagram yang memperlihatkan pemetaan software kepada hardware. Pemetaan tersebut adalah sebagai berikut:

\section{Dari sisi perusahaan :}

Sistem Aplikasi promosi dan generate report online akan diletakkan di application Server milik perusahaan, dimana semua data tentang services dan customer berikut dta pesanan akan disimpan di database server.Apllication server ini akan terhubung ke printer untuk mem-printout bukti pesanan customer, bukti pembayaran customer dan sales report.

\section{Dari sisi Customer:}

Customer bisa mengakses informasi ke website perusahaan dengan perantara Web server, baik itu lewat PC sendiri ataupun PC warnet.

\section{PENUTUP}

Sebagai perusahaan rental mobil yang cukup terkemuka indomobil rental car diharapkan dapat memberikan informasi yang selalu terupdate diwebsite untuk memenuhi kebutuhan informasi para pelanggan.Oleh karena itu dibuat solusi dari masalah yang terjadi pada perusahaan ini dengan pengembangan website Indomobil Rental Car agar lebih dinamis dan lebih menarik para pengunjung website.

\section{DAFTAR PUSTAKA}

Pressman, R. S. (2005). Software Engineering : A Practtitioner's Approach, $6^{\text {th }}$ Ed; New York: McGraw Hills.

Suhendar, A., \& Gunadi, H, (2002). Visual Modeling Menggunakan UML dan Rational Rose, Bandung: Informatika. 